\title{
Pengaruh Lingkungan Literasi di Kelas terhadap Kemampuan Membaca Permulaan Anak
}

\author{
Esra Sangelia Sinaga ${ }^{1 凶}$, Nurbiana Dhieni $^{2}$, Tjipto Sumadi ${ }^{3}$ \\ Pendidikan Anak Usia Dini, Universitas Negeri Jakarta Afiliasi \\ DOI: $\underline{10.31004 / \text { obsesi.v6i1.1225 }}$
}

\begin{abstract}
Abstrak
Kemampuan membaca permulaan adalah tahap awal anak belajar membaca yang berkaitan dengan upaya pertamanya memahami bahasa tulis. Lingkungan literasi adalah salah satu faktor yang mempengaruhi kemampuan membaca permulaan. Selain lingkungan rumah, anak juga mendapatkan stimulasi dari sekolah, sehingga perlu untuk melihat pengaruh kualitas lingkungan literasi di kelas terhadap kemampuan membaca permulaan. Penelitian ini bertujuan untuk mendeskripsikan lingkungan literasi di kelas dalam mempengaruhi kemampuan membaca permulaan. Penelitian ini menggunakan pendekatan kualitatif dengan teknik kajian pustaka yang bersumber dari buku dan literatur terdahulu sesuai dengan topik penelitian. Teknik analisis data dalam penelitian ini terdiri dari reduksi data, penyajian data dan menarik kesimpulan. Hasil menunjukkan bahwa lingkungan literasi di kelas mempengaruhi kemampuan membaca permulaan. Ruang kelas dengan sumber literasi yang kaya dan penataan yang sesuai mendukung perkembangan kemampuan membaca permulaan. Hal ini perlu diketahui agar pihak sekolah memahami pentingnya membangun lingkungan literasi yang baik di kelas untuk mendukung perkembangan kemampuan membaca permulaan anak.
\end{abstract}

Kata Kunci: kemampuan membaca permulaan; lingkungan literasi di kelas; anak usia dini

\begin{abstract}
Emergent reading is the early stage of children learning to read. Literacy environment is one of factors that affects emergent reading. Beside at home, children also get stimulation at school, so it is necessary to see the effect of the literacy environment in the classroom to emergent reading. The objective of this study is to describe the effects of the literacy environment in the classroom to emergent reading. This is a qualitative study that presents a literature review of books and journal articles related to the topic. The data analysis technique consists of data reduction, data display and conclusions. Literature results show that the literacy environment in the classroom contributes to emergent reading. Literacy enriched classroom environments provides children the opportunities to improve the emergent reading. This needs to be known so that school understands the importance of a good literacy environment in the classroom to support emergent reading development.
\end{abstract}

Keywords: emergent reading; literacy environment; early childhood

Copyright (c) 2021 Esra Sangelia Sinaga, Nurbiana Dhieni, Tjipto Sumadi

$\triangle$ Corresponding author:

Email Address : esrasinagaa@gmail.com (Jakarta, Indonesia)

Received 15 April 2021, Accepted 24 April 2021, Published 27 April 2021 


\section{PENDAHULUAN}

Pendidikan anak usia dini merupakan fondasi yang penting untuk mendukung pertumbuhan dan perkembangan anak agar memiliki kesiapan belajar dalam memasuki pendidikan lebih lanjut. Salah satu program pengembangan utama dalam pendidikan anak usia dini adalah pengembangan bahasa. Sebagai bagian perkembangan bahasa anak, membaca merupakan keterampilan yang penting dalam pembelajaran anak di masa sekolah. Keterampilan membaca sangat diperlukan untuk memasuki jenjang pendidikan di tingkat sekolah dasar. Kemampuan membaca dimaknai sebagai kemampuan dalam mengenal huruf atau aksara, membunyikan huruf atau rangkaian huruf-huruf (kata), serta memahami makna atau maksud dari kata dan bacaan (Carroll, Bowyer-Crane, Duff, Hulme, \& Snowling, 2011). Sebagaimana ditunjukan dengan data tentang pengenalan membaca permulaan oleh Wulansari, Hafidah, dan Pudyaningtyas (2018), dari 12 anak terdapat 25\% atau sejumlah 3 anak yang mendapat nilai tuntas, sedangkan $75 \%$ atau sejumlah 9 anak belum tuntas. Indikator ketuntasan terletak pada kemampuan menyebutkan simbol-simbol huruf yang dikenal, memasangkan tulisan sederhana dengan gambar atau simbol, dan membaca kata sederhana. Begitu juga yang ditunjukkan dalam hasil observasi yang dilakukan oleh Sulistyoningsih (2015), Agustin (2017), dan Rachmawaty (2017), diketahui bahwa dari seluruh anak dalam kelas, lebih besar jumlah anak yang kemampuan membaca permulaannya masih belum berkembang dengan baik. Kemampuan membaca permulaan pada anak dapat terlihat berdasarkan pengetahuan huruf yang dimiliki oleh anak (Pertiwi, 2016). Jika anak mampu mengenal berbagai huruf dengan baik dan lancar, maka akan membantu mempermudah anak dalam mengeja. Dan sebaliknya, jika anak belum mampu atau memiliki pengetahuan huruf yang masih rendah maka anak akan kesulitan memasuki tahapan berikutnya.

Pengalaman literasi anak pada usia prasekolah diyakini akan membentuk fondasi yang kuat pada perkembangan kemampuan membacanya (Levy, Gong, Hessels, Evans, \& Jared, 2006). Stimulasi literasi bagi anak merupakan pengalaman anak terpapar dengan buku dan media tulisan lainnya, sebelum anak mulai mendapat pengajaran membaca dan menulis di sekolah dasar (Slavin, 2006). Salah satu faktor yang mempengaruhi kemampuan membaca permulaan anak adalah lingkungan. Perkembangan kemampuan membaca anak didukung oleh lingkungan literasi di sekitar anak. Pengalaman anak pada masa usia dini yang didukung dengan stimulasi melalui lingkungan yang kaya akan paparan literasi yang tepat adalah hal yang sangat penting (Cunningham, 2010). Lingkungan literasi yang kaya bermanfaat untuk membangun minat anak terhadap membaca dan menulis (Wildová \& Kropáčková, 2015). Pengalaman literasi anak pada usia prasekolah diyakini akan membentuk fondasi yang kuat pada perkembangan membacanya (Levy et al., 2006). Senada dengan Otto (2015) yang menyatakan bahwa eksplorasi terhadap literasi yang dilakukan anak terjadi ketika anak berada dalam lingkungan yang menyediakan ruang dan interaksi membaca dan menulis.

Tentang pengaruh lingkungan literasi di sekitar anak, beberapa penelitian memotret lingkungan literasi di rumah yang berkontribusi pada perkembangan kemampuan membaca permulaan anak. Neeltje J. Davidse beserta rekan-rekannya dari Leiden University (2011), menemukan adanya hubungan antara paparan buku dengan pengetahuan kosakata dan huruf oleh anak. Senada dengan penelitian ekperimental yang dilakukan oleh Hamilton, Hayiou-Thomas, Hulme, dan Snowling (2016), yang mengukur lingkungan literasi di rumah pada anak-anak disleksia dan anak-anak tanpa risiko disleksia. Penelitian tersebut menunjukkan hasil bahwa anak-anak dengan disleksia dapat menikmati manfaat dari interaksi literasi yang kaya dengan tingkat yang sama dengan anak-anak lain. Selain lingkungan rumah, anak juga mendapatkan stimulasi dari sekolah, sehingga perlu untuk melihat pengaruh kualitas lingkungan literasi di kelas terhadap kemampuan membaca permulaan anak. Hal ini perlu diketahui agar pihak sekolah memahami pentingnya membangun lingkungan literasi yang baik di kelas untuk mendukung perkembangan kemampuan membaca permulaan anak. 


\section{METODOLOGI}

Penelitian ini menggunakan metode penelitian kepustakaan seperti buku, artikel dan karya ilmiah terkait kemampuan membaca permulaan anak dan lingkungan literasi di kelas untuk melihat apakah lingkungan literasi di kelas mempengaruhi kemampuan membaca permulaan anak usia dini dengan tahapan seperti pada Gambar 1 (Zed, 2008). Penelitian ini penting dilakukan untuk memberikan informasi kepada pembaca bahwa kemampuan membaca permulaan merupakan tahap awal anak belajar membaca dan dipengaruhi oleh lingkungan sekitar anak, terkhususnya lingkungan literasi di kelas.

Instrumen dalam penelitian ini adalah peneliti sendiri. Sumber data dalam penelitian ini adalah data sekunder, berupa kajian pustaka terdahulu yang sesuai dengan topik penulisan artikel ini yaitu, lingkungan literasi di kelas dan kemampuan membaca permulaan. Teknik pengumpulan data yang dilakukan adalah dokumentasi, yaitu pengumpulan catatan atau peristiwa yang didapat dari artikel atau sumber daring lain yang sesuai dengan topik artikel. Hasil dari beberapa pustaka yang telah ditelaah ini akan digunakan untuk mengidentifikasi pengaruh lingkungan literasi di kelas terhadap kemampuan membaca permulaan anak usia dini. Tahapan penelitian kepustakaan yang digunakan dapat dilihat pada gambar 1.
1. Mengumpulkan data pustaka sebagai bahan penelitian

\section{Membuat \\ catatan \\ penelitian}

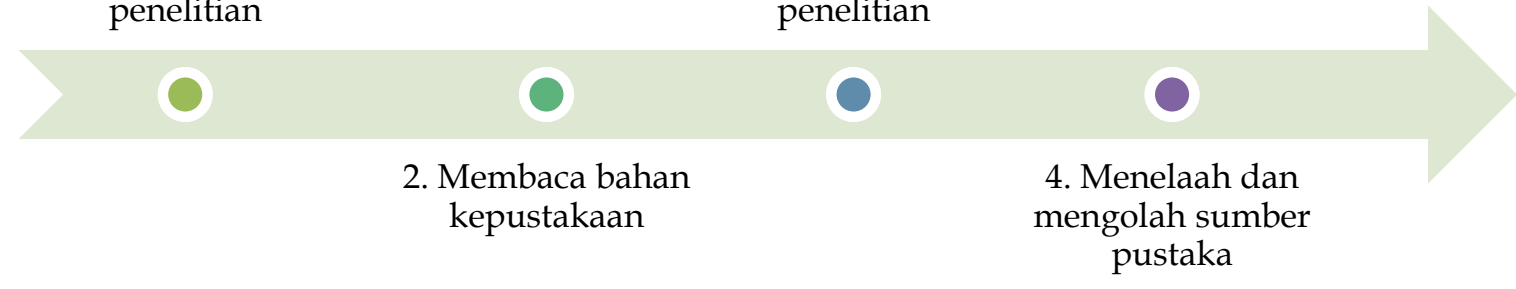

Gambar 1. Tahap Penelitian Kepustakaan

\section{HASIL DAN PEMBAHASAN}

\section{Kemampuan Membaca Permulaan}

Sebelum seorang anak mampu membaca lanjutan atau membaca lancar, mereka terlebih dulu mengembangkan kemampuan membaca permulaan. Banyak penelitian membuktikan bahwa kemampuan membaca permulaan menentukan pencapaian akademis anak di jenjang pendidikan selanjutnya. Seperti penelitian yang dilakukan oleh Cunningham dan Stanovich (1997) yang menunjukkan bahwa kemampuan membaca permulaan anak adalah prediktor yang kuat untuk mengukur kemampuan membaca lanjutan. Lonigan, Burgess, \& Anthony (2000)) juga membuktikan bahwa kemampuan membaca anak saat di sekolah dasar dapat diprediksi dari kemampuan membaca permulaan yang muncul di masa pra sekolah. Begitu juga dengan Ehri (2005), dalam penelitiannya menemukan bahwa pengetahuan tentang huruf dalam perkembangan membaca permulaan anak meningkatkan kemampuan belajar anak tentang kosa kata baru, dan mempengaruhi memori mereka dua kali lipat dalam mempelajari kata. Hasil yang serupa dibuktikan oleh Ecalle, Biot-Chevrier, dan Magnan (2008), bahwa kemampuan membaca permulaan yang baik sangat mempengaruhi kemampuan membaca anak berikutnya.

Kemampuan membaca permulaan atau emergent reading adalah istilah yang digunakan untuk tahap awal anak belajar membaca yang berkaitan dengan upaya pertamanya untuk memahami bahasa tulis seperti mengenal simbol-simbol atau tanda-tanda yang berkaitan dengan huruf-huruf (Teale \& Sulzby, 1986; Whitehurst \& Lonigan, 1998; New \& Cochran, 2007). Keterampilan yang diperlukan mencakup kemampuan untuk mengenal huruf dan kata, mencocokkan huruf dengan bunyi serta menggabungkan rangkaian bunyi untuk membuat 
kata-kata. Pada periode ini, anak belajar bahwa apa yang tercetak sebagai bahasa tulis mewakili kata yang diucapkan sebagai bahasa lisan (New \& Cochran, 2007). Kemampuan membaca permulaan lebih diorientasikan pada kemampuan membaca tingkat dasar atau kemampuan melek huruf (Fitria \& Suparno, 2016). Anak dapat mengubah dan melafalkan lambang tertulis menjadi bunyi bermakna.

Ada beberapa pendapat tentang tahapan membaca seorang anak. Research Triangle Institute (RTI) dari USAID menjabarkan karakteristik perkembangan membaca pada tahap permulaan (emergent) di antaranya adalah anak memperhatikan lingkungan kelas yang kaya akan bahan cetakan, anak menunjukkan minat pada buku, anak mencoba untuk membaca, anak menggunakan media gambar dan menyimpulkan pola-pola yang dapat diprediksi dari buku untuk menceritakan kembali cerita, anak membaca ulang teks yang familiar dengan pola-pola yang dapat diprediksi, anak mengidentifikasi berbagai tulisan tentang nama-nama, serta anak mengenali 5-20 kata-kata yang familiar atau yang sering muncul dalam bacaan (USAID, 2014). Steinberg dalam Susanto (2011) menjabarkan empat tahapan perkembangan membaca pada anak usia dini, yaitu (1) Tahap timbulnya kesadaran terhadap tulisan, (2) Tahap membaca gambar, (3) Tahap pengenalan bacaan, dan (4) Tahap membaca lancar. Sementara menurut Cochrane Efal sebagaimana dikutip Brewer (2006), perkembangan kemampuan membaca permulaan pada usia 4-6 tahun berlangsung dalam 5 tahap (Ismaniar, Jamaris, \& Wisroni, 2019), yaitu 1. Tahap Fantasi (Magical Stage), saat anak mulai belajar mengenal buku, mulai berpikir bahwa buku ini penting, melihat atau membolakbalikkan buku dan membawa buku kesenangannya, 2. Tahap Pembentukan Konsep Diri (Self Concept Stage), saat anak memandang dirinya sebagai pembaca dan mulai melibatkan diri dalam kegiatan membaca, pura-pura membaca buku, memberi makna pada gambar dengan menggunakan bahasa meskipun tidak cocok dengan tulisan, 3. Tahap Membaca Gambar (Bridging Reading Stage), saat anak menjadi sadar dengan cetakan yang sudah dikenal, dapat mengungkapkan kata-kata yang memiliki makna yang dekat dengan dirinya, dapat mengulang kembali cerita yang tertulis, dapat mengenal cetakan kata dalam sebuah tulisan yang dikenalnya serta sudah mengenal abjad, 4. Tahap Pengenalan Bacaan (Take-Off Reader Stage), saat anak mulai secara bersamaan tertarik pada bacaan, mulai mengingat kembali tulisan dan maknanya, berusaha mengenal tanda-tanda pada lingkungan sekitarnya serta membaca berbagai simbol seperti pada kotak susu, pasta gigi atau papan iklan, dan 5. Tahap Membaca Lancar, saat anak dapat membaca beragam buku yang berbeda, menangkap makna dari sebuah simbol, dan dapat membuat kesimpulan dari apa yang dibacanya.

Aspek perkembangan membaca permulaan anak usia dini secara spesifik berpusat pada beberapa komponen seperti pengenalan kata, perkembangan kosakata, kelancaran bicara, pemahaman akan tulisan dan kaitannya dengan simbol (Kennedy et al., 2012). Sebagaimana yang dilakukan dalam penelitian Syarifatul Fitria dan Suparno (2016) yang mengukur kemampuan membaca permulaan 15 anak kelas A di TK Fastrack Funschool menggunakan indikator menyebutkan nama karakter huruf, menyebutkan bunyi huruf, mencocokkan huruf besar dan kecil, menyebutkan tulisan sederhana dengan simbol yang melambangkannya. Sementara Get Ready to Read! Screening Tool (GRTR, 2001) yang dikembangkan oleh Whitehurst dan Lonigan dan Test of Preschool Early Literacy (TOPEL, 2007) yang dikembangkan oleh Lonigan, Wagner, Torgesen, dan Rashotte, keduanya mengukur kemampuan membaca permulaan anak usia dini dengan menilai anak dalam hal pengenalan akan cetakan, pemahaman kata, dan kesadaran fonologi (Wilson \& Lonigan, 2010). Pengenalan akan cetakan mengukur pengetahuan akan konsep cetakan, membedakan huruf, membedakan kata, identifikasi simbol huruf, dan identifikasi bunyi huruf. Pemahaman kata mengukur kosakata tunggal yang anak ucapkan dan kemampuan anak merumuskan definisi sebuah kata. Kesadaran fonologi mengacu pada kemampuan untuk mengenal suara dalam suatu sistem bahasa sesuai tahap perkembangan anak. 
Dengan demikian, dari pemaparan ahli di atas mengenai kemampuan membaca permulaan dapat dideskripsikan bahwa kemampuan membaca permulaan adalah tahap awal bagi anak usia dini belajar membaca yang meliputi kesanggupan untuk mengenal huruf dari simbol dan bunyinya, serta mampu mengidentifikasi huruf dan membedakannya, membaca sederhana dan menarik kesimpulan mengenai maksud bacaan.

\section{Lingkungan Literasi di Kelas}

Lingkungan dimana anak hidup atau tinggal mempengaruhi perkembangan anak dan merupakan salah satu faktor yang mendukung perkembangan kemampuan membacanya. Pengalaman anak pada masa usia dini yang didukung dengan stimulasi melalui lingkungan yang kaya akan paparan literasi yang tepat dan dikelola dengan baik adalah hal yang sangat penting untuk perkembangan kemampuan membaca permulaannya (Cunningham, 2010). Otto (2015) menyatakan bahwa eksplorasi terhadap literasi yang dilakukan anak terjadi ketika anak berada dalam lingkungan yang menyediakan ruang dan interaksi membaca dan menulis. Lingkungan yang memberikan stimulasi literasi pada anak usia dini atau disebut sebagai lingkungan literasi (Griffin \& Morrison, 1997). Lingkungan literasi yang kaya bermanfaat untuk membangun minat anak terhadap membaca dan menulis (Wildová \& Kropáčková, 2015). Bahkan lingkungan literasi yang baik berkontribusi pada perkembangan literasi awal anak usia dini dengan tunarungu (Easterbrooks, Lederberg, \& Connor, 2010). Korelasi menunjukkan bahwa lingkungan literasi erat kaitannya dengan peningkatan kosakata dan kesadaran fonologis pada anak tunarungu. Pengalaman literasi anak pada usia dini diyakini akan membentuk fondasi yang kuat pada perkembangan membacanya (Levy et al., 2006).

Rumah merupakan lingkungan pertama tempat anak bertumbuh dan berkembang, sehingga lingkungan literasi di rumah memainkan peran penting dalam mempengaruhi perkembangan literasi awal dan kesiapan membaca anak. Dalam penelitiannya, Lee dan Yeo (2014) menemukan hubungan yang signifikan antara lingkungan literasi di rumah dengan sikap membaca anak. Neeltje J. Davidse beserta rekan-rekannya dari Leiden University (2011), menelaah hubungan antara paparan buku dan keterampilan literasi permulaan dan menemukan hasil bahwa membaca buku cerita anak memediasi hubungan antara lingkungan literasi di rumah dan keterampilan membaca anak, serta menemukan adanya hubungan antara paparan buku dengan pengetahuan kosakata dan huruf oleh anak. Senada dengan penelitian ekperimental yang dilakukan oleh Hamilton, Hayiou-Thomas, Hulme, dan Snowling (2016), mengukur lingkungan literasi di rumah pada anak-anak disleksia dan anakanak tanpa risiko disleksia menunjukkan hasil bahwa anak-anak dengan disleksia dapat menikmati manfaat dari interaksi literasi yang kaya dengan tingkat yang sama dengan anakanak lain.

Lingkungan literasi yang dimaksud berkaitan dengan desain dan penataan ruang kelas, serta sumber daya materi yang dapat diakses oleh anak-anak di kelas. Dalam ruang kelas bagi anak usia dini, sumber daya materi literasi mencakup buku, bahan tulisan, simbol, dan alat peraga yang berhubungan dengan keaksaraan. Salah satu instrumen yang dapat digunakan untuk mengukur kualitas lingkungan literasi berupa fisik bagi anak usia dini adalah Literacy Environment Checklist dalam ELLCO (Early Language and Literacy Classroom Observation) (Baroody \& Diamond, 2014). Secara garis besar, Literacy Environment Checklist mengukur penataan lingkungan literasi di dalam kelas termasuk ke dalam aspek lingkungan fisik seperti tata ruang kelas, akses kepada media literasi, serta pengelolaan berbagai sumber literasi. Penataan kelas juga memperhatikan ketersediaan buku-buku yang menarik dan beragam serta keberadaan tempat duduk yang nyaman untuk anak membaca buku-buku tersebut. Begitu juga tempat untuk menulis yang disesuaikan bagi anak usia dini dapat ditemukan alat dan bahan menulis yang bervariasi untuk membangun berbagai pengalaman menulis. Bahan-bahan cetak yang tersedia di ruang kelas berkaitan dengan tema kelas dan bermakna bagi anak untuk dapat memperkaya pengalaman belajar mereka. 
Berdasarkan penjabaran di atas, dapat dideskripsikan bahwa lingkungan literasi adalah keberadaan lingkungan dan sumber literasi yang bermakna yang terwujud dalam penataan ruang kelas dan ketersediaan media atau sumber literasi, cetakan atau bacaan untuk anak usia dini, seperti buku, simbol, huruf, dan atau gambar, serta alat dan bahan tulis menulis yang sesuai dengan perkembangan anak usia dini dengan tujuan menciptakan pengalaman literasi yang kaya dan merangsang perkembangan literasi anak usia dini.

\section{Pengaruh Lingkungan Literasi di Kelas terhadap Kemampuan Membaca Permulaan}

Selain lingkungan di rumah, lingkungan literasi di sekolah juga mempengaruhi kemampuan membaca permulaan anak (Guo, Justice, Kaderavek, \& McGinty, 2012). Di sekolah, ketersediaan sumber literasi di dalam kelas memiliki efek yang positif terhadap kemampuan anak mengenal huruf (Miller, 2016). Lingkungan literasi di kelas memainkan peran penting dalam mempengaruhi perkembangan literasi awal dan kesiapan membaca anak usia dini (Wolfersberger, Reutzel, Sudweeks, \& Fawson, 2004). Sebagaimana yang dibuktikan oleh Baroody dan Diamond (2014) dalam penelitiannya, bahwa lingkungan literasi di kelas memiliki korelasi positif dengan minat dan keterlibatan anak dalam kegiatan membaca dan kemampuan membaca permulaan 167 anak berusia 4 sampai dengan 5 tahun. Dalam melakukan pengamatan terhadap lingkungan literasi, Baroody dan Diamond menggunakan Literacy Environment Checklist dalam ELLCO (Early Language and Literacy Classroom Observation) sebagai instrumen. Data mengenai lingkungan literasi di kelas yang dikumpulkan berkaitan dengan tata kelola ruang dan ketersediaan sumber literasi seperti buku, simbol, huruf, dan atau gambar, serta alat dan bahan tulis menulis sesuai dengan perkembangan anak usia dini, yang tata letaknya diatur sedemikian rupa untuk menciptakan pengalaman literasi dan mendukung perkembangan literasi anak.

Selain mendapatkan stimulasi dari guru di lembaga PAUD tempat anak belajar, lingkungan literasi di kelas berupa fisik (physical literacy environment) yang berkualitas baik juga merupakan bentuk stimulasi yang dapat diberikan untuk meningkatkan kemampuan membaca permulaan anak (Guo, Sawyer, Justice, \& Kaderavek, 2013). Rebecca Capen (2010) dalam McAllister (2012) menyebutkan bahwa keseluruhan lingkungan kelas, baik komponen sosial dan fisik dapat menambah atau mengurangi motivasi membaca anak. Senada dengan yang disampaikan oleh Morrow and Rand (1991) dalam McAllister (2012) bahwa lingkungan literasi sangat penting dalam mendukung dan aktif mempengaruhi pembelajaran literasi anak. Ruang kelas yang kaya literasi menyediakan lingkungan yang kaya akan cetakan untuk mendukung pertumbuhan literasi dan pemahaman yang mendalam tentang tingkat pengembangan literasi anak (Paratore \& McCormack, 2007; Morrow, 2007). Lingkungan literasi di kelas pada Taman Kanak-Kanak terwujud dalam lingkungan kelas yang kaya akan cetakan atau bacaan untuk anak usia dini, seperti buku, simbol-simbol huruf, dan atau gambar yang sesuai dengan perkembangan anak usia dini.

Lingkungan literasi yang baik di kelas diharapkan dapat menumbuhkan motivasi anak dalam belajar membaca dan bermanfaat untuk membangun minat anak terhadap membaca dan menulis (Wildová \& Kropáčková, 2015). Dalam penelitiannya, Wolfersberger et al. (2004) dan Siron (2019), menemukan bahwa guru-guru pendidikan anak usia dini menyadari terdapat pengaruh lingkungan kelas terhadap pembelajaran dan perilaku anak ketika mereka mendesain, menata, dan menampilkan berbagai benda, perabot dalam kelas. Guru menyediakan akses kepada anak untuk dapat berinteraksi dengan lingkungan literasi yang disediakan di kelas sepanjang hari dan secara sadar terstruktur untuk mengoptimalkan pembelajaran literasi anak (Hoffman, Sailors, Duffy, \& Beretvas, 2004). Senada dengan yang disampaikan oleh Morrow and Rand (1991) dalam McAllister (2012) bahwa lingkungan literasi sangat penting dalam mendukung dan aktif mempengaruhi pembelajaran literasi anak. Dalam penelitiannya sendiri McAllister menggunakan Early Childhood Environment Rating Scale menemukan bahwa keberadaan sejumlah apparatus literasi di kelas menunjukkan pengaruh bagi perkembangan literasi anak. 
Dengan demikian, dari hasil kajian pustaka yang telah dipaparkan diatas, disimpulkan bahwa lingkungan literasi di kelas mempengaruhi kemampuan membaca permulaan anak usia dini. Hal ini dikarenakan ruang kelas dengan sumber literasi yang kaya dan penataan yang sesuai akan memberikan akses kepada anak untuk berinteraksi terhadap literasi dan membangun pengalaman belajar serta mendukung perkembangan kemampuan membaca permulaannya.

\section{SIMPULAN}

Lingkungan literasi di kelas merupakan salah satu faktor yang mempengaruhi kemampuan membaca permulaan anak usia dini. Keberadaan lingkungan literasi yang baik di dalam kelas terwujud dalam penataan ruang dan ketersediaan sumber literasi yang bermakna serta sesuai dengan perkembangan anak usia dini dengan tujuan menciptakan pengalaman literasi yang kaya dan merangsang perkembangan literasi anak usia dini. Ruang kelas dengan sumber literasi yang kaya dan penataan yang sesuai memberikan akses kepada anak untuk berinteraksi dengan literasi dan membangun pengalaman belajar anak serta mendukung perkembangan kemampuan membaca permulaannya.

\section{UCAPAN TERIMA KASIH}

Penulis mengucapkan terima kasih kepada dosen pembimbing atas bimbingan dan dukungan dalam menyelesaikan penulisan artikel ini menjadi lebih baik dan penulis mengucapkan terima kasih kepada berbagai pihak yang telah mendukung dan membantu penyelesaian artikel ini.

\section{DAFTAR PUSTAKA}

Agustin, D. (2017). Peningkatan Kemampuan Membaca Permulaan pada Anak Kelompok B2 Melalui Media Stiker Alfabet di TK Dharma Indria II Sumbersari Jember Tahun Pelajaran 2016/2017. Retrieved from https:/ / repository.unej.ac.id/handle/123456789/81326

Baroody, A. E., \& Diamond, K. E. (2014). Associations Among Preschool Children's Classroom Literacy Environment, Interest and Engagement in Literacy Activities, and Early Reading Skills. Journal of Early Childhood Research, 14(2), 146-162. https://doi.org/10.1177/1476718X14529280

Carroll, J. M., Bowyer-Crane, C., Duff, F. J., Hulme, C., \& Snowling, M. J. (2011). Developing Language and Literacy: Effective Intervention in the Early Years. West Sussex: John Wiley \& Sons Ltd. https://doi.org/10.1002/9780470977460

Cunningham, A. E., \& Stanovich, K. E. (1997). Early Reading Acquisition and Its Relation to Reading Experience and Ability 10 Years Later. Developmental Psychology, 33(6), 934945. https:// doi.org/10.1037/0012-1649.33.6.934

Cunningham, D. D. (2010). Relating Preschool Quality to Children's Literacy Development. Early Childhood Education Journal, 37(6), 501-507. https://doi.org/10.1007/s10643009-0370-8

Davidse, N. J., Jong, M. T. de, Bus, A. G., Huijbregts, S. C. J., \& Swaab, H. (2011). Cognitive and Environmental Predictors of Early Literacy Skills. Reading and Writing, 24(4), 395-412. https://doi.org/10.1007/s11145-010-9233-3

Easterbrooks, S. R., Lederberg, A. R., \& Connor, C. M. (2010). Contributions of the Emergent Literacy Environment to Literacy Outcomes for Young Children Who Are Deaf. American Annals of the Deaf, 155(4), 467-480. https://doi.org/10.1353/aad.2010.0024

Ecalle, J., Biot-Chevrier, C., \& Magnan, A. (2008). Alphabet Knowledge and Early Literacy Skills in French Beginning Readers. European Journal of Developmental Psychology, 5(3), 303-325. https://doi.org/10.1080/17405620600901714 
Ehri, L. C. (2005). Learning to Read Words: Theory, Findings, and Issues. Scientific Studies of Reading, 9(2), 167-188. https:// doi.org/10.1207/s1532799xssr0902_4

Fitria, S., \& Suparno. (2016). Evaluasi Pembelajaran Keterampilan Membaca Permulaan di TK Fastrack Funschool Kelas A Program Nusantara Yogyakarta. Jurnal Pendidikan Dan Pemberdayaan Masyarakat, 3(1), 85-96. https://doi.org/10.21831/jppm.v3i1.6481

Griffin, E. A., \& Morrison, F. J. (1997). The Unique Contribution of Home Literacy Environment to Differences in Early Literacy Skills. Early Child Development and Care, 127(1), 233-243. https:/ / doi.org/10.1080/0300443971270119

Guo, Y., Justice, L. M., Kaderavek, J. N., \& McGinty, A. (2012). The Literacy Environment of Preschool Classrooms: Contributions to Children's Emergent Literacy Growth. Journal of Research in Reading, 35(3), 308-327. https://doi.org/10.1111/j.14679817.2010.01467.x

Guo, Y., Sawyer, B. E., Justice, L. M., \& Kaderavek, J. N. (2013). Quality of the Literacy Environment in Inclusive Early Childhood Special Education Classrooms. Journal of Early Intervention, 35(1), 40-60. https:/ / doi.org/10.1177/1053815113500343

Hamilton, L. G., Hayiou-Thomas, M. E., Hulme, C., \& Snowling, M. J. (2016). The Home Literacy Environment as a Predictor of the Early Literacy Development of Children at Family-Risk of Dyslexia. Scientific Studies of Reading, 20(5), 401-419. https:// doi.org/10.1080/10888438.2016.1213266

Hoffman, J. V., Sailors, M., Duffy, G. R., \& Beretvas, S. N. (2004). The Effective Elementary Classroom Literacy Environment: Examining the Validity of the TEX-IN3 Observation System. Journal of Literacy Research, 36(3), 303-334. https:// doi.org/10.1207/s15548430j1r3603_3

Ismaniar, Jamaris, \& Wisroni. (2019). Stimulation of GrosImproving Children's Early Reading Skills Using Home Environmental Print Models Motor Development in Early Childhood. 5th International Conference on Education and Technology, 382(Advances in Social Science, Education and Humanities Research), 403-406. https:// doi.org/10.2991/icet-19.2019.101

Kennedy, E., Dunphy, E., Dwyer, B., Hayes, G., McPhillips, T., Marsh, J., ... Shiel, G. (2012). Literacy in Early Childhood and Primary Education. In National Council for Curriculum and Assessment. Retrieved from

Lee, M., \& Yeo, K. (2014). Influence of Home Literacy Environment on Children Reading Attitude. Journal of Education and Practice, 5(8), 119-138. Retrieved from https://www.iiste.org/Journals/index.php/JEP/article/view/11648/11991

Levy, B. A., Gong, Z., Hessels, S., Evans, M. A., \& Jared, D. (2006). Understanding Print: Early Reading Development and The Contributions of Home Literacy Experiences. Journal of Experimental Child Psychology, 93(1), 63-93. https:// doi.org/10.1016/i.jecp.2005.07.003

Lonigan, C. J., Burgess, S. R., \& Anthony, J. L. (2000). Development of Emergent Literacy and Early Reading Skills in Preschool Children: Evidence From a Latent-Variable Longitudinal Study. 36(5), 596-613. https://doi.org/10.1037/0012-1649.36.5.596

McAllister, K. J. (2012). Classroom Environment and Literacy Engagement: A Case Study of One Pre-Kindergarten Classroom (State University of New York at Fredonia). Retrieved from https://dspace.sunyconnect.suny.edu/bitstream/handle/1951/58323/Kayla_McAlli ster_Masters_Project_May2012.pdf?sequence=1

Miller, C. L. (2016). Elements of Process Quality Within a Preschool's Language and Early Literacy Environment: The Influence on Children's Pre-Reading and Writing Performance in the Beginning of Kindergarten. In ProQuest LLC. Retrieved from https://pqdtopen.proquest.com/doc/1791148663.html?FMT=ABS

Morrow, L. M. (2007). Developing Literacy in Preschool. In Choice Reviews Online (Vol. 45). https://doi.org/10.5860/CHOICE.45-5117 
New, R. S., \& Cochran, M. (2007). Literacy. In Early Childhood Education: An International Encyclopedia. Connecticut: Praeger Publishers.

Otto, B. (2015). Perkembangan Bahasa Pada Anak Usia Dini. Jakarta: Prenadamedia Group.

Paratore, J. R., \& McCormack, R. L. (2007). Classroom Literacy Assessment. New York: The Guilford Press.

Pertiwi, A. D. (2016). Study Deskriptif Proses Membaca Permulaan Anak Usia Dini. Jurnal Pendidikan Anak, 5(1), 759-764. https:// doi.org/10.21831/jpa.v5i1.12372

Rachmawaty, M. (2017). Peningkatan Kemampuan Membaca Permulaan Melalui Dinding Kata (Word Wall). Indria, 2(I), 12-27. Retrieved from http://journal.umpo.ac.id/index.php/indria/article/view/465/435 https://doi.org/10.24269/jin.v2n1.2017.pp28-44

Research Triangle Institute USAID. (2014). Buku Sumber Untuk Dosen LPTK: Pembelajaran Literasi Kelas Awal SD/MI di LPTK. North Carolina: RTI International.

Siron, Y. (2019). Kendala Guru PAUD Mengembangkan Sentra Membaca dan Menulis (Studi Kasus di Jakarta Timur). Cakrawala Dini: Jurnal Pendidikan Anak Usia Dini, 10(2), 145150.

https://ejournal.upi.edu/index.php/cakrawaladini/article/view/15212/10628 https://doi.org/10.17509/cd.v10i2.15212

Slavin, R. E. (2006). Educational Psychology: Theory and Practice. In British Journal of Psychiatry (Eight, Vol. 181). https:// doi.org/10.1192/bjp.181.5.440

Sulistyoningsih, E. (2015). Mengembangkan Kemampuan Membaca Permulaan Melalui Metode Bernyanyi dengan Huruf dan Kata pada Anak Kelompok A TK Dharma Wanita 1 Sidomulyo Kecamatan Wates Kabupaten Kediri. Simki-Pedagogia, 1(1), 1-13. Retrieved from http://simki.unpkediri.ac.id/mahasiswa/file_artikel/2016/11.1.01.11.0640.pdf

Susanto, A. (2011). Perkembangan Anak Usia Dini: Pengantar Dalam Berbagai Aspeknya. Jakarta: Kencana.

Teale, W. H., \& Sulzby, E. (1986). Emergent Literacy: Writing and Reading. New Jersey: Ablex Publishing Corporation.

Whitehurst, G. J., \& Lonigan, C. J. (1998). Child Development and Emergent Literacy. Child Development, 69(3), 848-872. https://doi.org/10.2307/1132208

Wildová, R., \& Kropáčková, J. (2015). Early Childhood Pre-reading Literacy Development. Procedia - Social and Behavioral Sciences, 191, 878-883. https://doi.org/10.1016/j.sbspro.2015.04.418

Wilson, S. B., \& Lonigan, C. J. (2010). Identifying Preschool Children at Risk of Later Reading Difficulties: Evaluation of Two Emergent Literacy Screening Tools. Journal of Learning Disabilities, 43(1), 62-76. https://doi.org/10.1177/0022219409345007

Wolfersberger, M. E., Reutzel, D. R., Sudweeks, R., \& Fawson, P. C. (2004). Developing and Validating the Classroom Literacy Environmental Profile (CLEP): A Tool for Examining the "Print Richness" of Early Childhood and Elementary Classrooms. $\begin{array}{llll}\text { Journal of } & \text { Literacy 211-272. }\end{array}$ https://doi.org/10.1207/s15548430jlr3602_4

Wulansari, T. E. C., Hafidah, R., \& Pudyaningtyas, A. R. (2018). Peningkatan Kemampuan Pengenalan Membaca Permulaan Melalui Permainan Tebak Kata Pada Anak Kelompok B TK/RA Cemara Dua Surakarta Tahun Ajaran 2015/2016. Kumara Cendikia, 5(1), 1-5. Retrieved https://jurnal.uns.ac.id/kumara/article/view/35002/22873

Zed, M. (2008). Metode Penelitian Kepustakaan. Jakarta: Yayasan Obor Indonesia. 